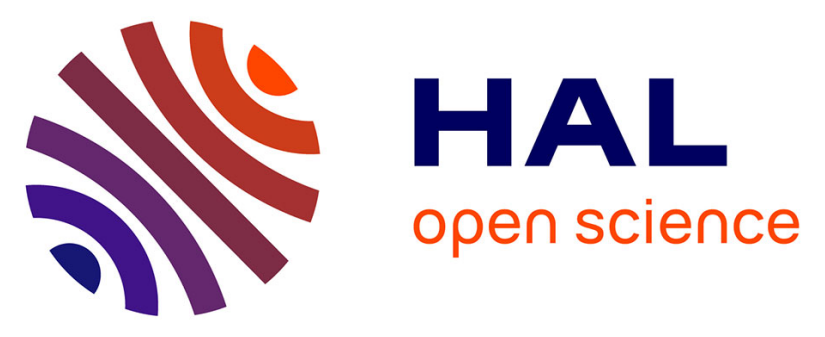

\title{
Experimental and computational investigations of phosphine exchange in 15-electron [CrCpCl2(PR3)] systems by stopped-flow and density functional calculations: a single-state SN2 mechanism
}

\author{
Edmond Collange, David Duret, Rinaldo Poli
}

\section{To cite this version:}

Edmond Collange, David Duret, Rinaldo Poli. Experimental and computational investigations of phosphine exchange in 15-electron [ $\mathrm{CrCpCl} 2(\mathrm{PR} 3)]$ systems by stopped-flow and density functional calculations: a single-state SN2 mechanism. Journal of the Chemical Society Dalton Transactions, 1999, 1999 (6), pp.875-880. 10.1039/A809129C . hal-03304774

\author{
HAL Id: hal-03304774 \\ https://hal.science/hal-03304774
}

Submitted on 4 Oct 2021

HAL is a multi-disciplinary open access archive for the deposit and dissemination of scientific research documents, whether they are published or not. The documents may come from teaching and research institutions in France or abroad, or from public or private research centers.
L'archive ouverte pluridisciplinaire HAL, est destinée au dépôt et à la diffusion de documents scientifiques de niveau recherche, publiés ou non, émanant des établissements d'enseignement et de recherche français ou étrangers, des laboratoires publics ou privés. 
Experimental and computational investigations of phosphine exchange in 15-electron [ $\left.\mathrm{CrCpCl}_{2}\left(\mathrm{PR}_{3}\right)\right]$ systems by stopped-flow and density functional calculations: a single-state $S_{\mathrm{N}} 2$ mechanism

Edmond Collange, David Duret and Rinaldo Poli*

Laboratoire de Synthèse et d'Electrosynthèse Organométalliques, Faculté des Sciences "Gabriel”, Université dé Bourgogne, 6 Boulevard Gabriel, 21100 Dijon, France

Correspondence to: Prof. Rinaldo Poli

Laboratoire de Synthèse et d'Electrosynthèse Organometalliques

Faculté des Sciences "Gabriel"

6, Boulevard Gabriel

21100 Dijon (France)

tel: $+33-03.80 .39 .68 .81$

fax: $+33-03.80 .39 .60 .98$

E-MAIL: poli@u-bourgogne.fr 


\section{Abstract}

The exchange of the phosphine ligand on the half-sandwich 15-electron, spin quartet $\left[\mathrm{CrCpCl}_{2} \mathrm{~L}\right]$ system has been investigated experimentally by stopped-flow kinetics with visible detection and theoretically by calculations with DFT methods on the $\mathrm{PH}_{3}$ self-exchange model system. The exchange of $\mathrm{PMePh}_{2}$ with $\mathrm{PMe}_{3}$ follows clean second-order kinetics with the activation parameters $\Delta H^{*}=7.0(2) \mathrm{kcal} \mathrm{mol}^{-1}$ and $\Delta S^{\ddagger}=-24.3(8) \mathrm{cal} \mathrm{K}^{-1} \mathrm{~mol}^{-1}$, consistent with an associative exchange. The rate constant for the exchange of $\mathrm{L}$ with $\mathrm{PMe}_{3}$ in $\left[\mathrm{CrCpCl}_{2} \mathrm{~L}\right]$ at room temperature varies only within a factor of 8 for the series of complexes with $\mathrm{L}=\mathrm{PPh}_{3}$, $\mathrm{PMePh}_{2}, \mathrm{PMe}_{2} \mathrm{Ph}, \mathrm{PEt}_{3}$, or $\eta^{1}$-dppe. The computational work showed that the $\mathrm{PH}_{3}$ selfexchange process occurs via a symmetric transition state along the spin quartet hypersurface, without crossover to the spin doublet state. The optimized transition state corresponds to a firstorder saddle point with $\mathrm{Cr}-\mathrm{P}$ distances of 3.190 and $3.174 \AA$, located $7.6 \mathrm{kcal} \mathrm{mol}^{-1}$ above the $\left[\mathrm{CrCpCl}_{2}\left(\mathrm{PH}_{3}\right)\right]$ (spin quartet) $+\mathrm{PH}_{3}$ combination, or $13.6 \mathrm{kcal} \mathrm{mol}^{-1}$ below the $\left[\mathrm{CrCpCl}_{2}\left(\mathrm{PH}_{3}\right)_{2}\right]$ doublet minimum. Thus, the phosphine exchange reaction can be classified as a classical $S_{N} 2$ process.

\section{Introduction}

The organometallic chemistry of $\mathrm{Cr}^{\mathrm{III}}$ has boomed in recent years, in large part because of its implication in the Phillips process for ethylene polymerization. ${ }^{1}$ The first reported chromium(III) organometallic complex was the pseudooctahedral complex $\left[\mathrm{CrEt}\left(\mathrm{H}_{2} \mathrm{O}\right)_{5}\right]^{2+}$, followed only a few years later by half-sandwich derivatives of types $\mathrm{CrCpX}_{2} \mathrm{~L}$ and $\mathrm{CrCpX}_{3}{ }^{-}$ $\left(\mathrm{X}=\mathrm{Cl}, \mathrm{Br}\right.$ or $\mathrm{I} ; \mathrm{L}=$ py, THF or $\left.\mathrm{PPh}_{3}\right){ }^{3}$ Subsequently, many other similar half-sandwich complexes containing alkyl groups, phosphines, $\mathrm{Cp}^{*}$, and other ligands were described by several groups including ours. ${ }^{1,4-14}$ The dicationic aqua complexes $\left[\mathrm{CrCp}\left(\mathrm{H}_{2} \mathrm{O}\right)_{3}\right]^{2+}$ and $\left[\mathrm{CrCp} *\left(\mathrm{H}_{2} \mathrm{O}\right)_{3}\right]^{2+}$ have also been described. ${ }^{15,16}$ Apart from particular cases where the formation of dinuclear compounds with metal-metal bonds is favored, ${ }^{17-19}$ these systems are overwhelmingly seen to adopt an open shell, spin quartet, 15-electron configuration which can be related to the ubiquitous octahedral configuration of classical Werner-type complexes. They strongly resist co-ordination by another 2-electron donor which would bring the electron count to 17 , i.e. closer to the closed-shell configuration, but also necessarily involve an energetically quite costly (for chromium) pairing of electrons. This behavior is opposite from that of the neighbouring molybdenum, which prefers a spin-paired 17-electron configuration in view of 
stronger metal-ligand bonds and reduced electron pairing energies. These considerations, which have been backed-up by computational studies at both the ab initio and density functional levels, ${ }^{20,21}$ may be generalized to all open-shell organometallic systems. ${ }^{22,23}$ In the absence of steric effects, the relative stability of 15 -and 17-electron systems for $\mathrm{Cr}^{\mathrm{III}}$ and $\mathrm{Mo}^{\mathrm{III}}$ relative to the association/dissociation of a 2-electron donor ligand may be qualitatively summarized as illustrated in the reaction coordinates (a) through (d) of Scheme $1,{ }^{23}$ corresponding to an increasing degree of electron pairing energy.

(a)
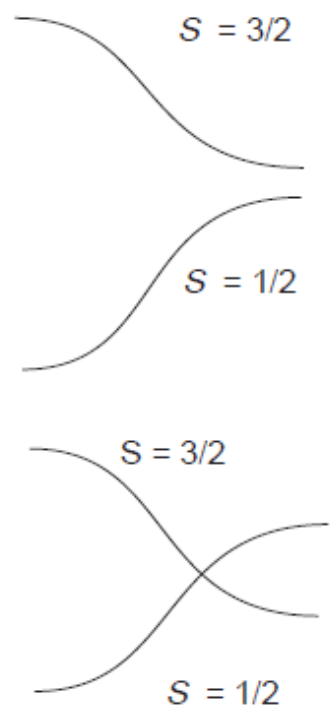

(c)

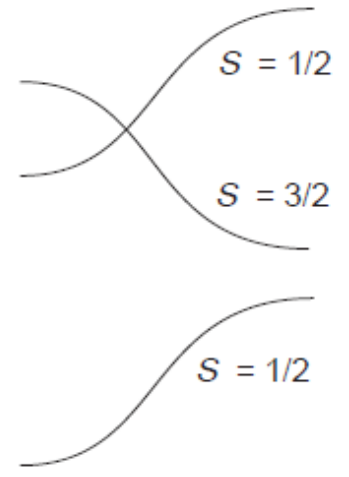

(d)

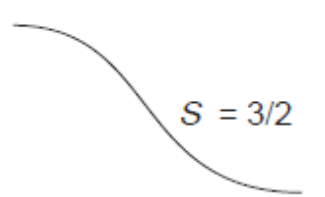

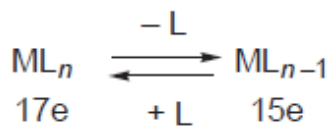

\section{Scheme 1}

Bulky ligands and/or ligands that establish relatively weak bonds lead to the stabilization of even less saturated (13-electron) configurations. Examples are $\left[\mathrm{Na}\left(\mathrm{OEt}_{2}\right)_{2}\right]\left[\mathrm{Na}\left(\mathrm{OEt}_{2}\right)\right.$ (THF) $]\left[\mathrm{CrPh}_{5}\right]^{24}$ or, for half-sandwich complexes, $\left[\mathrm{CrCp}^{*} \mathrm{Cl}\left(\mathrm{CH}_{2} \mathrm{SiMe} 3\right)\right]$ and $\left[\mathrm{CrCp}^{*}\right.$ $\left.\left(\mathrm{CH}_{2} \mathrm{SiMe}_{3}\right)_{2}\right]^{1,25}$ Also, the activity of $\left[\mathrm{CrCp} * \mathrm{R}(\mathrm{THF})_{2}\right]^{+},\left[\mathrm{CrCp}^{*} \mathrm{R}\left(\mathrm{OEt}_{2}\right)_{2}\right]^{+}$, and $\left[\mathrm{CrCp}^{*}\right.$ $\left.\left(\mathrm{CH}_{2} \mathrm{Ph}\right)_{3} \mathrm{Li}\right]$ as polymerization catalysts has been attributed to dissociation equilibria with $13-$ electron species which can bind and activate the olefin substrate. ${ }^{1}$ On the other hand, we have recently shown that the use of the strongly bonding and highly nephelauxetic $\mathrm{CN}^{-}$ligand allows the stabilization, in solution, of the spin-paired, 17-electron complexes $\left[\mathrm{Cr}(\operatorname{ring})(\mathrm{CN})_{4}\right]^{2-}($ ring $=\mathrm{Cp}$ or $\left.\mathrm{Cp}^{*}\right)$ and $\left[\mathrm{CrCp}(\mathrm{CN})_{2} \mathrm{~L}_{2}\right](\mathrm{L}=$ tertiary phosphine $) .{ }^{26}$ Another 17-electron complex of $\mathrm{Cr}^{\mathrm{III}}$, albeit stable only at low temperatures, is $\left[\mathrm{CrCp}\left(\eta^{3}-\mathrm{C}_{3} \mathrm{H}_{5}\right)_{2}\right] .{ }^{27} \mathrm{On}$ the basis of all the above 
it is clear that the chromium(III) center in organometallic systems has the ability to accommodate a variety of different coordination spheres and electron counts.

In view of the relevance that the half-sandwich chromium(III) system has to the olefin polymerization process, we considered it of interest to probe the mechanism of fundamental chemical transformations on model compounds in this electronic configuration. The reaction that we have chosen for our initial studies is the exchange of a phosphine ligand on the $\left[\mathrm{CrCpCl}_{2}\left(\mathrm{PR}_{3}\right)\right]$ system. A dissociative exchange process would parallel the dissociation of $\mathrm{L}$ from $\left[\mathrm{CrCp}^{*} \mathrm{RL}_{2}\right]^{+}\left(\mathrm{L}=\mathrm{THF}\right.$ or $\left.\mathrm{Et}_{2} \mathrm{O}\right)$ to generate the proposed active species in ethylene polymerization catalysis. An associative process, on the other hand, could generate a species having the same configuration as the stable 17-electron $\left[\mathrm{MoCpCl}_{2}\left(\mathrm{PR}_{3}\right)_{2}\right]$ or the cyanosubstituted chromium(III) derivatives mentioned above. The latter process could involve a spin flip from a quartet state in the starting material to a doublet in the intermediate, and then back to a quartet in the product, thus representing a new case of the so-called two-state reactivity (TSR), ${ }^{28,29}$ namely a reaction occurring on two different spin surfaces. ${ }^{30-32}$

The phosphine exchange process on the 17-electron molybdenum(III) complexes $\left[\mathrm{Mo}(\right.$ ring $\left.) \mathrm{Cl}_{2}\left(\mathrm{PMe}_{3}\right)_{2}\right]$ (ring $=\mathrm{Cp}$ or $\mathrm{Cp}^{*}$ ) was conveniently investigated by monitoring the growth of the ${ }^{31} \mathrm{P}$ NMR resonance of free $\mathrm{PMe}_{3}$ upon treatment with a large excess of $\mathrm{PMe}_{3}-d^{9}$ ( $t_{1 / 2}$ of the order of hours at room temperatures), allowing the establishment of a first order (dissociative) process. Preliminary studies of the analogous exchange for the $\left[\mathrm{CrCpCl}_{2}\left(\mathrm{PMe}_{3}\right)\right]$ system have shown that the reaction is complete within the time necessary to record the first NMR spectrum, thus the reaction is too fast for classical monitoring kinetics studies. ${ }^{33}$ On the other hand, the addition of $\mathrm{PMe}_{3}$ to a solution of $\left[\mathrm{CrCpCl}_{2}\left(\mathrm{PMe}_{3}\right)\right]$ does not significantly affect the line shape of the resonances of free and co-ordinated $\mathrm{PMe}_{3},{ }^{33}$ thus the reaction is too slow for the application of NMR line broadening kinetic studies. Consequently, we turned to nondegenerate, quantitative phosphine exchange reactions and to the use of the stopped-flow kinetics methodology. We report here our experimental investigations of various $\left[\mathrm{CrCpCl}_{2}\left(\mathrm{PR}_{3}\right)\right]+\mathrm{PMe}_{3}$ reactions, and a parallel computational study along the reaction coordinate for the model $\left[\mathrm{CrCpCl}_{2}\left(\mathrm{PH}_{3}\right)\right]+\mathrm{PH}_{3}$ system.

\section{Experimental}


All operations were carried out under an atmosphere of dinitrogen. Solvents were dehydrated by conventional methods and distilled directly from the dehydrating agent prior to use (THF from sodium-benzophenone and toluene from Na). Compounds $\left[\mathrm{CrCpCl}_{2} \mathrm{~L}\right](\mathrm{L}=$ $\mathrm{PEt}_{3}, \mathrm{PMe}_{2} \mathrm{Ph}, \mathrm{PMePh}_{2}, \mathrm{PPh}_{3}$, or $\eta^{1}$-dppe) were prepared as previously described. ${ }^{5,12,13}$ Solutions of $\mathrm{PMe}_{3}[1 \mathrm{M}$ in THF and $1 \mathrm{M}$ in toluene (Aldrich)] were used as received.

The stopped-flow kinetic investigations were carried out with a Hi-Tech DX2 apparatus, equipped with a xenon lamp $(75 \mathrm{~W})$ and a KinetaScan diode array UV-visible detector. The data were analysed with the SPECFIT global analysis package ${ }^{34}$ on a Pentium PC.

Theoretical calculations were carried out by GAUSSIAN $94^{35}$ on a SGI Origin 200 workstation. The three-parameter form of the Becke, Lee, Yang and Parr functional (B3LYP) ${ }^{36}$ was employed. The LanL2DZ basis set includes both Dunning and Hay's D95 sets for H and $\mathrm{C}^{37}$ and the relativistic electron core potential (ECP) sets of Hay and $\mathrm{Wadt}^{38-40}$ for the heavy atoms. Electrons outside the core were all those of $\mathrm{H}$ and $\mathrm{C}$ atoms, the $3 \mathrm{~s}, 3 \mathrm{p}$ electrons in $\mathrm{Cl}$ and $\mathrm{P}$, and the $3 \mathrm{~s}, 3 \mathrm{p}, 3 \mathrm{~d}$ and $4 \mathrm{~s}$ electrons in Cr. A Cs symmetry arrangement was imposed for the $\left[\mathrm{CrCpCl}_{2}\left(\mathrm{PH}_{3}\right)_{\mathrm{n}}\right]$ systems $(\mathrm{n}=1$ or 2$)$ at each fixed $\mathrm{Cr} \cdots \mathrm{P}$ distance. The transition state calculation was carried out with a Synchronous Transit-Guided Quasi-Newton (QST2) algorithm. The energies shown in the Results section correspond to unrestricted B3LYP (UB3LYP) calculations. The value of $\left\langle S^{2}\right\rangle$ at convergence was in the range $0.7503-0.7504$ for all spin doublet calculations and in the range 3.7527-3.7630 for all spin quartet calculations.

\section{Results and discussion}

The exchange reaction (1) $\left(\mathrm{PR}_{3}=\mathrm{PPh}_{3}, \mathrm{PPh}_{2} \mathrm{Me}, \mathrm{PPhMe}_{2}, \mathrm{PEt}_{3}\right.$ or $\eta^{1}$-dppe $)$ is quite rapid and quantitative at room temperature and is therefore amenable to kinetics investigations by the stopped-flow technique. The thermodynamic drive for the reaction is provided by the stronger bonds established by $\mathrm{PMe}_{3}$ with the chromium(III) center relative to the other phosphine ligands, presumably because of a combination of the stronger donating ability and the less stringent steric requirements of the $\mathrm{PMe}_{3}$ ligand. ${ }^{41}$ A similar trend of relative stability was observed for the related half-sandwich complexes of $\mathrm{Mo}^{\mathrm{III}} .31,42$

$$
\left[\mathrm{CrCpCl}_{2}\left(\mathrm{PR}_{3}\right)\right]+\mathrm{PMe}_{3} \rightarrow\left[\mathrm{CrCpCl}_{2}\left(\mathrm{PMe}_{3}\right)\right]+\mathrm{PR}_{3}
$$


The $\mathrm{PMePh}_{2}$ derivative was selected for carrying out detailed rate law and activation parameter investigations. Although both starting and final complexes are blue, the visible absorption spectra differ sufficiently, especially in the $450-700 \mathrm{~nm}$ region, to allow an accurate determination of kinetic parameters on the basis of variations up to 0.1 absorbance unit. The instrument background noise (and the residuals of the final data fittings) are below 1 milliabsorbance unit. Various kinetic runs were carried out under pseudo-first order conditions. Initial investigations were carried out in THF. The global analysis of the data obtained in this solvent, however, did not yield a satisfactory fit to a common single exponential for all absorption frequencies. An acceptable fit was obtained instead for an $\mathrm{A} \rightarrow \mathrm{B} \rightarrow \mathrm{C}$ model. The absorption spectra calculated with the SPECFIT global analysis program for A, B and C were qualitatively similar and suggest that all species are 15-electron half-sandwich derivatives of $\mathrm{Cr}^{\mathrm{III}}$. The most reasonable structural assignment of the different species appears to be the product of phosphine exchange, $\left[\mathrm{CrCpCl}_{2}\left(\mathrm{PMe}_{3}\right)\right]$, to $\mathrm{B}$ and the ionic product $\left[\mathrm{CrCpCl}\left(\mathrm{PMe}_{3}\right)_{2}\right]^{+} \mathrm{Cl}^{-}$, derived from substitution of a chloride ligand by a second $\mathrm{PMe}_{3}$ molecule, to $\mathrm{C}$. Under the above assumption, we reasoned that the second exchange process could be strongly retarded or completely suppressed upon carrying out the kinetic study in a less polar solvent, e.g. toluene.

Indeed, the investigation in toluene afforded clean single exponential decays, leading to the pseudo-first-order rate constants in Table 1. The graphic representation of the constants obtained at $25{ }^{\circ} \mathrm{C}$ as a function of the phosphine concentration (runs 1-4, see Fig. 1) immediately establishes a second-order rate law for this phosphine exchange reaction. From the slope of the straight line, the second-order rate constant $k=223 \pm 5 \mathrm{M}^{-1} \mathrm{~s}^{-1}$ is obtained at this temperature.

Table 1. Rate constants for the $\left[\mathrm{CrCpCl}_{2}\left(\mathrm{PMePh}_{2}\right)\right]+\mathrm{PMe}_{3}$ reaction in toluene. ${ }^{a}$

\begin{tabular}{ccccc}
\hline Run & $10^{-2}\left[\mathrm{PMe}_{3}\right] / \mathrm{M}$ & $\mathrm{T} / \mathrm{K}$ & $k_{\mathrm{obs}} / \mathrm{s}^{-1}$ & $10^{-2} \mathrm{k} / \mathrm{M}^{-1} \mathrm{~s}^{-1}$ \\
\hline 1 & 1.00 & 298 & $2.075(8)$ & \\
2 & 2.50 & 298 & $5.9(1)$ & \\
3 & 4.00 & 298 & $8.9(1)$ & \\
4 & 4.70 & 298 & $10.39(7)$ & \\
5 & 2.10 & 278 & $1.88(3)$ & $0.89(1)$ \\
6 & 2.10 & 288 & $3.09(3)$ & $1.47(1)$ \\
7 & 2.10 & 298 & $4.66(4)$ & $2.22(2)$ \\
8 & 2.10 & 308 & $7.29(6)$ & $3.47(3)$ \\
\hline
\end{tabular}

${ }^{a}$ Complex concentration $=1.23 \cdot 10^{-3} \mathrm{M}$ 


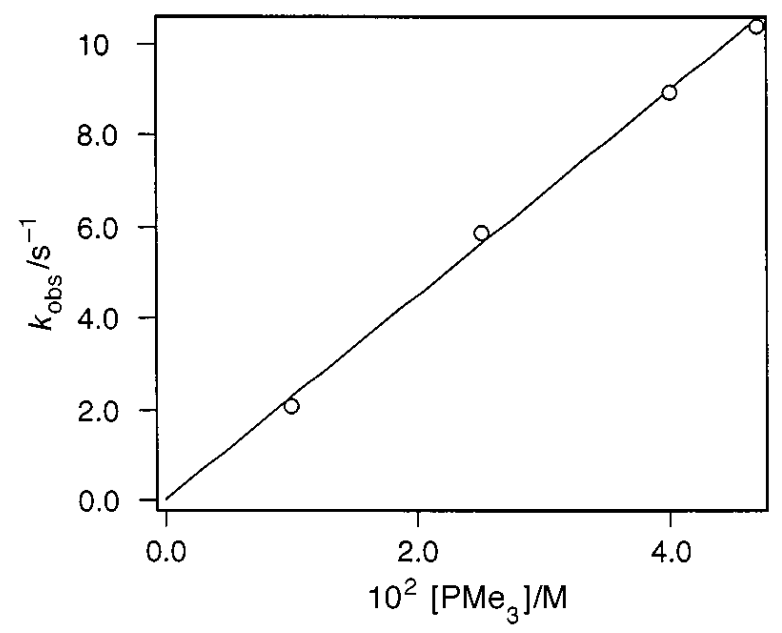

Fig. 1 Plot of $k_{\text {obs }} v s .\left[\mathrm{PMe}_{3}\right]$ for the reaction between $\left[\mathrm{CrCpCl}_{2}\left(\mathrm{PMePh}_{2}\right)\right]$ and $\mathrm{PMe}_{3}$ in toluene at $25^{\circ} \mathrm{C}$.

An investigation of the same reaction at the constant $\left[\mathrm{PMe}_{3}\right]:[\mathrm{Cr}]$ ratio of $17: 1$ and at different temperatures in the $5-35^{\circ} \mathrm{C}$ range (runs 5-8) yields a linear $\ln \left(k_{\mathrm{obs}} / T\right) v s .1 / T$ plot (Fig. 2), leading to the calculations of the activation parameters for the reaction: $\Delta H^{\ddagger}=7.0(2) \mathrm{kcal}$ $\mathrm{mol}^{-1}$ and $\Delta S^{\ddagger}=224.3(8) \mathrm{cal} \mathrm{K}^{-1} \mathrm{~mol}^{-1}$. The large negative activation entropy, together with the established second order rate law, is consistent with an associative mechanism involving a high degree of ordering in the transition state.

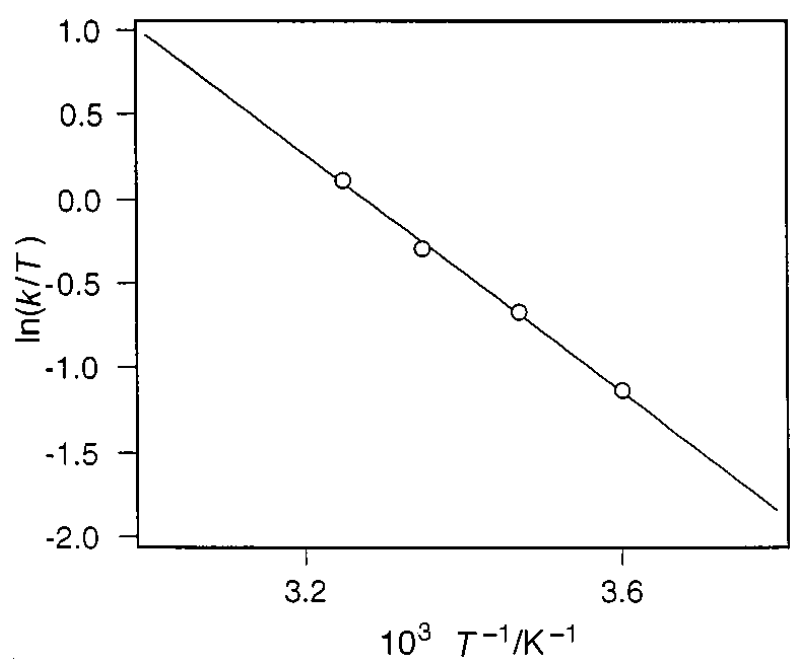

Fig. 2 Eyring plot for the reaction between $\left[\mathrm{CrCpCl}_{2}\left(\mathrm{PMePh}_{2}\right)\right]$ and $\mathrm{PMe}_{3}$ in toluene.

Kinetic investigations were also carried out for other starting materials as shown in eqn. (1). These were only determined at a single $\left[\mathrm{PMe}_{3}\right]:[\mathrm{Cr}]$ ratio and at a single temperature. The second order rate constants (see Table 2) were derived under the reasonable assumption that all these reactions occur by the same mechanism as the $\mathrm{PMePh}_{2} / \mathrm{PMe}_{3}$ exchange. The results are themselves further evidence in favor of a common associative mechanism for all these exchange 
reactions. For a pure dissociative process, the $\mathrm{Cr}-\mathrm{PR}_{3}$ bond would be broken in the slow step of the reaction. Consequently, the rate contants should be very sensitive to the nature of the phosphine ligand, the more weakly bonded phosphine ligands leading to faster exchange processes. Other systems that have previously been established to follow a dissociative ligand exchange, such as the 18-electron complex cis-[Mo(CO) $\left.{ }_{4} \mathrm{~L}_{2}\right]$, afford first order rate constants over 3 orders of magnitude smaller for $\mathrm{PMe}_{2} \mathrm{Ph}$ relative to $\mathrm{PPh}_{3} .{ }^{43}$ On the other hand, a pure associative process would involve the formation of the new $\mathrm{Cr}-\mathrm{PMe}_{3}$ bond, which is essentially the same for all systems. Consequently, the rate should only experience a slight dependence on the nature of the outgoing phosphine, the faster rates being expected for the least sterically encumbering and/or least electron donating phosphines. For the present system, the data in Table 2 show that the pseudo-first-order rate constant varies over a factor of only 8 on going from $\mathrm{PPh}_{3}$ to $\mathrm{PMe}_{2} \mathrm{Ph}$. In addition, the slower reaction is given by the $\mathrm{PPh}_{3}$ complex, consistent with a sterically controlled associative process and in strong disagreement with a dissociative process.

Table 2. Rate constants for the $\left[\mathrm{CrCpCl}_{2}\left(\mathrm{PMePh}_{2}\right)\right]+\mathrm{PMe}_{3}$ reaction in toluene. ${ }^{a}$

\begin{tabular}{cccc}
\cline { 2 - 3 } & $\mathrm{PR}_{3}$ & $k_{\mathrm{obs}} / \mathrm{s}^{-1}$ & $10^{-2} \mathrm{k} / \mathrm{M}^{-1} \mathrm{~s}^{-1}$ \\
\cline { 2 - 4 } $\mathrm{PPh}_{3}$ & $1.03(4)$ & $1.03(4)$ \\
$\eta^{1}-\mathrm{dppe}$ & $17(1)$ & $17(1)$ \\
$\mathrm{PMe}_{2} \mathrm{Ph}$ & $9(1)$ & $9(1)$ \\
${ }^{a}$ Complex concentration & $=5.00 \cdot 10^{-4} \mathrm{M},\left[\mathrm{PMe}_{3}\right]=1.00 \cdot 10^{-2} \mathrm{M}$
\end{tabular}

Fig. 3 shows the correlation between the second-order rate constants and Tolman's electronic and steric parameters. ${ }^{41}$ There is a poor correlation with both parameters for the entire series of compounds investigated. The three systems based on the homologous $\mathrm{PMe}_{\mathrm{n}} \mathrm{Ph}_{3-\mathrm{n}}$ series ( $\mathrm{n}=0,1$ or 2 ) show a linear correlation with both parameters, but the electronic parameters would be expected to lead to the opposite trend of reactivity $\left(\mathrm{PPh}_{3}>\mathrm{PMePh}_{2}>\mathrm{PMe}_{2} \mathrm{Ph}\right)$. Thus, these phosphine ligands influence the exchange rate mostly by virtue of their steric encumbrance. The $\mathrm{PEt}_{3}$ ligand shows an unusually slow rate when its steric requirements are compared with those of the $\mathrm{PMe}_{n} \mathrm{Ph}_{3-n}$ systems. The reason for this discrepancy may be either an important contribution of the electronic factor $\left[\mathrm{PEt}_{3}\right.$ is a much stronger donor than the $\mathrm{PMe}_{n} \mathrm{Ph}_{3-n}$ phosphines, see Fig. 3(a)], or by the gross underestimation of the actual steric 
encumbrance of $\mathrm{PEt}_{3}$ by Tolman's cone angle, ${ }^{44,45}$ or a combination of the two effects. A discrepancy that cannot be easily rationalized is the relatively fast exchange rate for the $\eta^{1}$-dppe complex. This ligand, when co-ordinated in a monodentate fashion, has electronic and steric parameters identical with those of $\mathrm{PMePh}_{2}$, yet it leads to an exchange rate constant ca. 7.5 times bigger than that furnished by $\mathrm{PMePh}_{2}$.

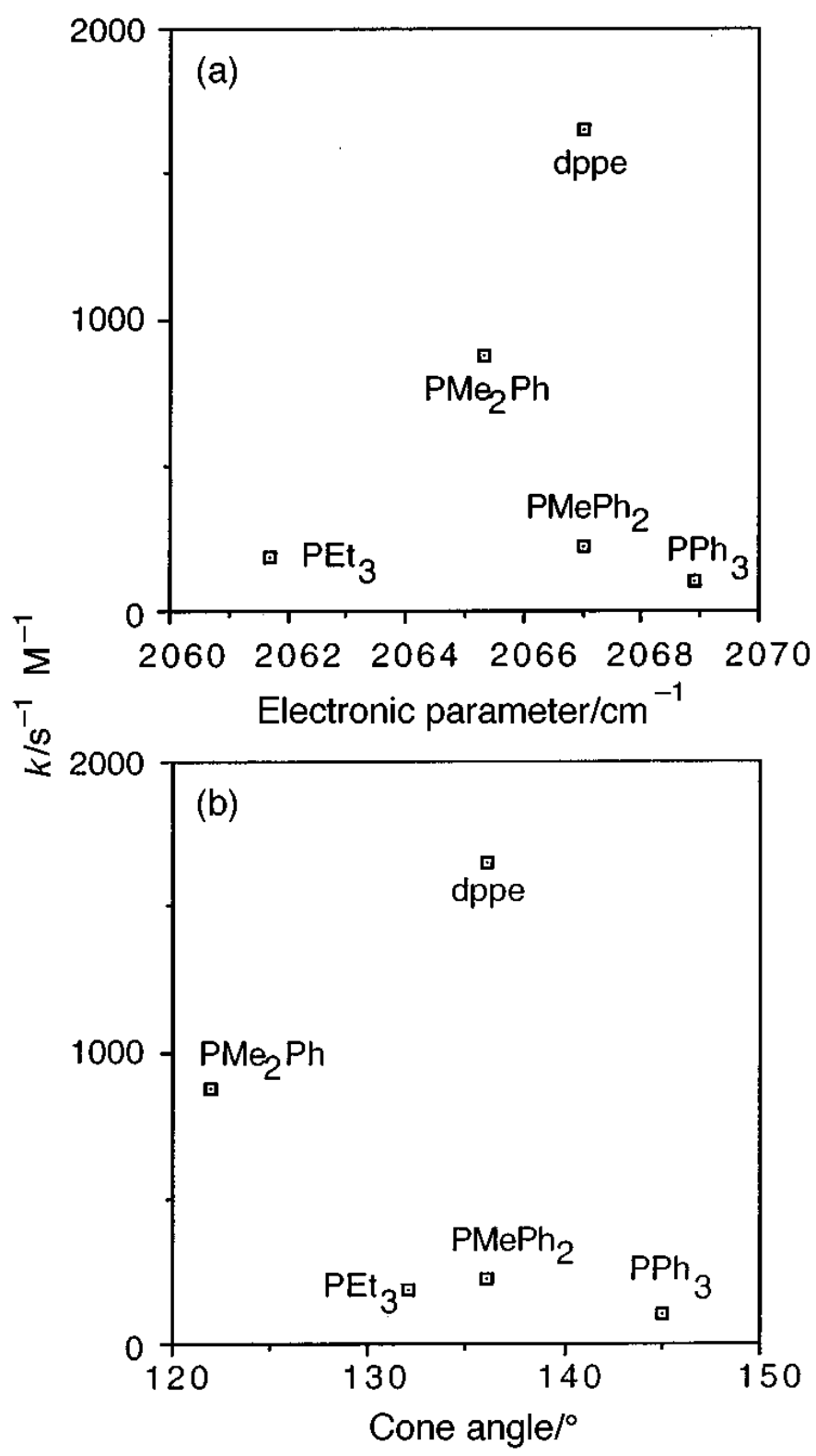

Fig. 3 Correlation between the second-order rate constant of the $\left[\mathrm{CrCpCl}_{2}\left(\mathrm{PR}_{3}\right)\right]+\mathrm{PMe}_{3}$ reaction and Tolman's electronic and steric parameters.

Although the rate law and the activation entropy strongly suggest an associative mechanism, these experimental data cannot distinguish between the formation of a distinct 17electron intermediate and an interchange transition state, nor whether a spin state change occurs 
along the reaction coordinate, namely whether this is a one-state or a two-state reaction. To help clarify this point, we have complemented our experimental studies with theoretical calculations.

Previous calculations with full geometry optimization on $\left[\mathrm{CrCpCl}_{2}\left(\mathrm{PH}_{3}\right)\right]$ (in the doublet and quartet states) and $\left[\mathrm{CrCpCl}_{2}\left(\mathrm{PH}_{3}\right)_{2}\right]$ (doublet state) at various levels of theory indicated that the combination of quartet $\left[\mathrm{CrCpCl}_{2}\left(\mathrm{PH}_{3}\right)\right]$ and free $\mathrm{PH}_{3}$ is at least $13.6 \mathrm{kcal} \mathrm{mol}{ }^{-1}$ more stable than doublet $\left[\mathrm{CrCpCl}_{2}\left(\mathrm{PH}_{3}\right)_{2}\right]{ }^{20,21}$ This is a substantially greater number than the measured activation enthalpy for the $\left[\mathrm{CrCpCl}_{2}\left(\mathrm{PMePh}_{2}\right)\right]+\mathrm{PMe}_{3}$ system, thus suggesting that the formation of a 17-electron intermediate having a doublet configuration may not occur.

Additional calculations on the spin doublet curve at various fixed distances between the $\mathrm{Cr}$ and the $\mathrm{P}$ atom of the entering $\mathrm{PH}_{3}$ ligand, with complete optimization of all other parameters, yield the results shown in Fig. 4. The minimum of this curve corresponds to the previously fully optimized spin doublet adduct which is located at 0.03375 hartree $(21.2 \mathrm{kcal}$ $\mathrm{mol}^{-1}$ ) above the $\left[\mathrm{CrCpCl}_{2}\left(\mathrm{PH}_{3}\right)\right]$ (spin quartet) $+\mathrm{PH}_{3}$ combination at the chosen level of theory.

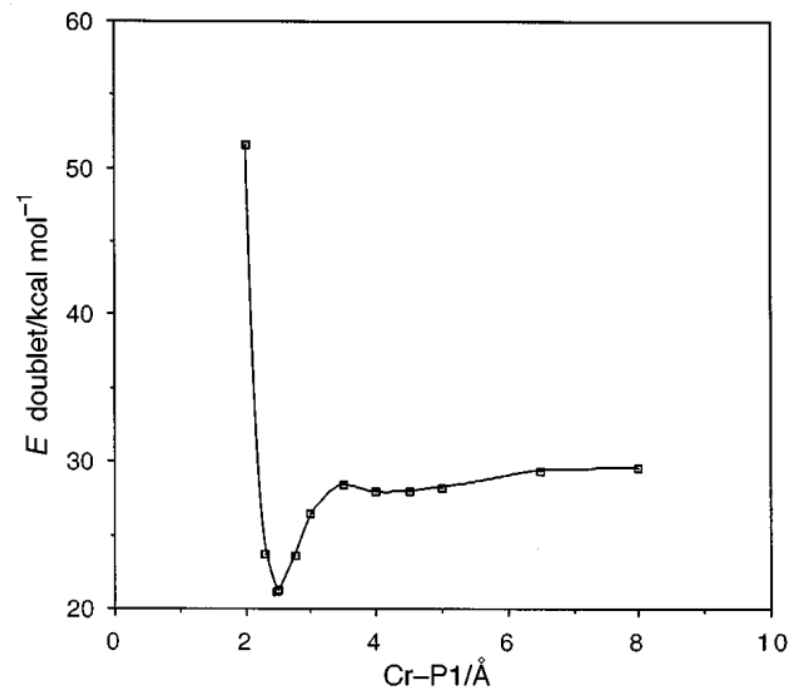

Fig. 4 Energy of the $\left[\mathrm{CrCpCl}_{2}\left(\mathrm{PH}_{3}\right)\right]+\mathrm{PH}_{3}$ system in the doublet spin state at various fixed distances between the $\mathrm{Cr}$ atom and the $\mathrm{P}$ atom of the incoming $\mathrm{PH}_{3}$ ligand. The energy (kcal $\left.\mathrm{mol}^{-1}\right)$ is relative to the $\left[\mathrm{CrCpCl}_{2}\left(\mathrm{PH}_{3}\right)\right](\mathrm{S}=3 / 2)+\mathrm{PH}_{3}$ system at infinite distance.

An analogous study along the quartet curve revealed the expected repulsive interaction upon approach of the incoming $\mathrm{PH}_{3}$ ligand, after an initial slight energy decrease. However, the energy of the system remained low relative to the bound doublet minimum and an elongation of the bond between $\mathrm{Cr}$ and the already co-ordinated $\mathrm{PH}_{3}$ ligand accompanied the approach of the incoming PH3 ligand. An attempt to optimize a structure with $\mathrm{Cr} \cdots \mathrm{P}<3 \AA$ led to the expulsion of the other $\mathrm{PH}_{3}$ ligand. A transition state calculation for the $\mathrm{PH}_{3}$ exchange provided 
a relatively symmetric geometry with $\mathrm{Cr}-\mathrm{P}$ distances of 3.190 and $3.174 \AA$, at an energy only 0.0122 hartree $\left(7.6 \mathrm{kcal} \mathrm{mol}^{-1}\right)$ above the $\left[\mathrm{CrCpCl}_{2}\left(\mathrm{PH}_{3}\right)\right]$ (spin quartet) $+\mathrm{PH}_{3}$ combination, or $13.6 \mathrm{kcal} \mathrm{mol}^{-1}$ below the bound doublet minimum. A frequency calculation confirms that this geometry corresponds to a first-order saddle point. The single imaginary frequency corresponds to the normal mode illustrated in Fig. 5, featuring the motion of one $\mathrm{P}$ atom toward the $\mathrm{Cr}$ atom and the other one away from it. The translation movement of the two $\mathrm{PH}_{3}$ ligands is accompanied by a slight rocking motion, tilting the $C_{3 \mathrm{v}}$ symmetry axis of the $\mathrm{PH}_{3}$ ligands from a direction collinear with the $\mathrm{Cr}-\mathrm{P}$ bond in the bonded geometry toward a direction collinear with the $\mathrm{Cr}-\mathrm{Cp}$ axis in the non-bonded geometry.

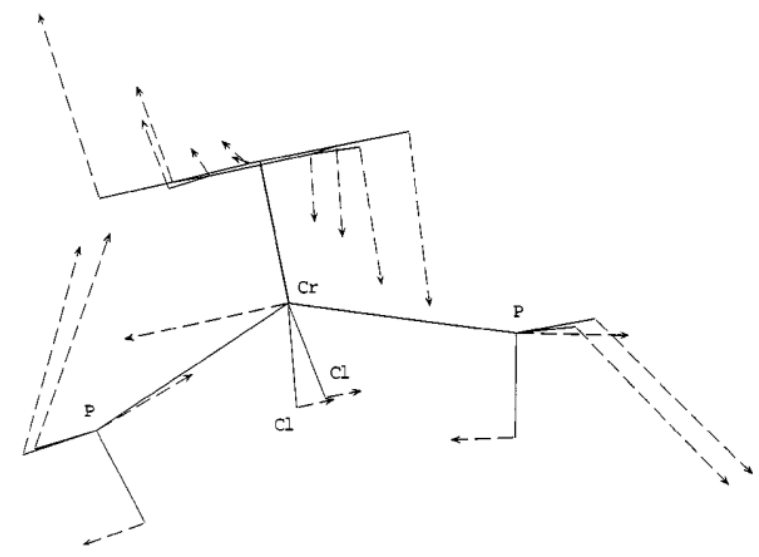

Fig. 5 Normal mode corresponding to the imaginary frequency of the first-order saddle point for the $\mathrm{PH}_{3}$ exchange reaction coordinate of the $\left[\mathrm{CrCpCl}_{2}\left(\mathrm{PH}_{3}\right)\right]+\mathrm{PH}_{3}$ system.

When extrapolated to the $\mathrm{PMe}_{3}$ system the calculation results indicate that the associative phosphine exchange is likely proceeding entirely on the spin quartet surface via a single symmetric transition state without crossover to the spin doublet surface, namely the reaction can be classified as a classical $\mathrm{S}_{\mathrm{N}} 2$ exchange, and corresponds to the situation represented in part (d) of Scheme 1. The calculated activation barrier for the associative self-exchange in the $\mathrm{PH}_{3}$ system is quite close to the measured enthalpic barrier to the exchange of $\mathrm{PMePh}_{2}$ by $\mathrm{PMe}_{3}$. These results may be relevant to the intimate mechanism of $\mathrm{CpCr}^{\mathrm{III}}$-catalysed olefin polymerization.

\section{Acknowledgments}

We are grateful to the Ministère de l'Education Nationale de la Recherche et de le Technologìe and the Centre National de la Recherche Scientifique for support of this work. We also thank the Région Bourgogne for equipment funding (Accueil de Nouvelles Equipes) and for providing part of the funds necessary for the purchase of the stopped-flow apparatus. 


\section{References}

1 K. H. Theopold, Eur. J. Inorg. Chem., 1998, 15 and refs. therein.

2 F. A. L. Anet and E. Leblanc, J. Am. Chem. Soc., 1957, 79, 2649.

3 E. O. Fischer, K. Ulm and P. Kuzel, Z. Anorg. Allg. Chem., 1963, 319, 253.

4 F. H. Köhler, R. de Cao, K. Ackermann and J. Sedlmair, Z. Naturforsch., Teil B, 1983, 38,1406 .

5 A. Grohmann, F. H. Köhler, G. Müller and H. Zeh, Chem. Ber., 1989, 122, 897.

6 F. H. Köhler, J. Lachmann, G. Müller, H. Zeh, H. Brunner, J. Pfauntsch and J. Wachter, J. Organomet. Chem., 1989, 365, C15.

7 B. J. Thomas, S. K. Noh, G. K. Schulte, S. C. Sendlinger and K. H. Theopold, J. Am. Chem. Soc., 1991, 113, 893.

8 G. Bhandari, Y. Kim, J. M. McFarland, A. L. Rheingold and K. H. Theopold, Organometallics, 1995, 14, 738.

9 G. Bhandari, A. L. Rheingold and K. H. Theopold, Chem. Eur. J., 1995, 1, 199.

10 P. A. White, J. Calabrese and K. H. Theopold, Organometallics, 1996, 15, 5473.

11 Y. Liang, G. P. A. Yap, A. L. Rheingold and K. H. Theopold, Organometallics, 1996, 15, 5284 .

12 J. C. Fettinger, S. P. Mattamana, R. Poli and R. D. Rogers, Organometallics, 1996, 15, 4211 .

13 M. Bender-Gresse, E. Collange, R. Poli and S. Mattamana, Polyhedron, 1998, 17, 1115.

14 O. Heinemann, P. W. Jolly, C. Krüger and G. P. J. Verhovnik, J. Organomet. Chem., 1998, 553, 477.

15 L. O. Spreer and I. Shah, Inorg. Chem., 1981, 20, 4025.

16 U. Koelle, Coord. Chem. Rev., 1994, 135, 623.

17 D. S. Richeson, W.-S. Hsu, N. H. Fredd, G. Van Duyne and K. H. Theopold, J. Am. Chem. Soc., 1986, 108, 8273. 
18 S. K. Noh, S. C. Sendlinger, C. Janiak and K. H. Theopold, J. Am. Chem. Soc., 1989, $111,9127$.

19 C. Janiak, J. Silvestre and K. H. Theopold, Chem. Ber., 1993, 126, 631.

20 I. Cacelli, D. W. Keogh, R. Poli and A. Rizzo, New J. Chem., 1997, 21, 133.

21 I. Cacelli, D. W. Keogh, R. Poli and A. Rizzo, J. Phys. Chem. A, 1997, 101, 9801.

22 R. Poli, Chem. Rev., 1996, 96, 2135.

23 R. Poli, Acc. Chem. Res., 1997, 30, 494.

24 E. Müller, J. Krause and K. Schmiedeknecht, J. Organomet. Chem., 1972, 44, 127.

25 J. A. Barrera and D. E. Wilcox, Inorg. Chem., 1992, 31, 1745.

26 S. P. Mattamana and R. Poli, Organometallics, 1997, 16, 2427.

27 K. Angermund, A. Döhring, P. W. Jolly, C. Krüger and C. C. Romão, Organometallics, 1986, 5, 1268.

28 S. Shaik, M. Filatov, D. Schröder and H. Schwarz, Chem. Eur. J., 1998, 4, 193.

29 S. Shaik, D. Danovich, A. Fiedler, D. Schröder and H. Schwarz, Helv. Chim. Acta, 1995, $78,1393$.

30 H. H. Brintzinger, L. L. Lohr, Jr. and K. L. T. Wong, J. Am. Chem. Soc., 1975, 97, 5146.

31 A. A. Cole, J. C. Fettinger, D. W. Keogh and R. Poli, Inorg. Chim. Acta, 1995, 240, 355.

32 D. W. Keogh and R. Poli, J. Am. Chem. Soc., 1997, 119, 2516.

33 R. Poli and S. P. Mattamana, unpublished work.

34 R. A. Binstead and A. D. Zuberbühler, Spectrum Software Associates, Chapel Hill, NC, 1993-1997.

35 M. J. Frisch, G. W. Trucks, H. B. Schlegel, P. M. W. Gill, B. G. Johnson, M. A. Robb, J. R. Cheeseman, T. A. Keith, G. A. Petersson, J. A. Montgomery, K. Raghavachari, M. A. Al-Laham, V. G. Zakrzewski, J. V. Ortiz, J. B. Foresman, J. Cioslowski, B. B. Stefanov, A. Nanayakkara, M. Challacombe, C. Y. Peng, P. Y. Ayala, W. Chen, M. W. Wong, J. L. Andres, E. S. Replogle, R. Gomperts, R. L. Martin, D. J. Fox, J. S. Binkley, D. J. Defrees, 
J. Baker, J. P. Stewart, M. Head-Gordon, C. Gonzales and J. A. Pople, GAUSSIAN 94, Revision E.1. Gaussian Inc., Pittsburgh, PA, 1995.

36 A. D. Becke, J. Chem. Phys., 1993, 98, 5648.

37 T. H. Dunning, Jr. and P. J. Hay, in Modern Theoretical Chemistry, ed. H. F. Schaefer, III, Plenum, New York, 1976, p. 1.

38 P. J. Hay and W. R. Wadt, J. Chem. Phys., 1985, 82, 270.

39 W. R. Wadt and P. J. Hay, J. Chem. Phys., 1985, 82, 284.

40 P. J. Hay and W. R. Wadt, J. Chem. Phys., 1985, 82, 299.

41 C. A. Tolman, Chem. Rev., 1977, 77, 313.

42 R. Poli, B. E. Owens, S. T. Krueger and A. L. Rheingold, Polyhedron, 1992, 11, 2301.

43 D. J. Darensbourg and A. H. Graves, Inorg. Chem., 1979, 18, 1257.

44 L. Stahl and R. D. Ernst, J. Am. Chem. Soc., 1987, 109, 5673.

45 T. L. Brown and K. J. Lee, Coord. Chem. Rev., 1993, 128, 89. 